\title{
ROLE OF INSECT VISITS ON CUCUMBER (Cucumis sativus L.) YIELD
}

\author{
Hossain, M. S., F. Yeasmin, M. M. Rahman, S. Akhtar ${ }^{1}$ and M. A. Hasnat \\ Department of Entomology, Sher-e-Bangla Agricultural University, Dhaka, Bangladesh; ${ }^{1}$ Krishi \\ Gobeshona Foundation, BARC Campus, Farmgate, Dhaka, Bangladesh
}

\begin{abstract}
The foraging activities of insect visitors on cucumber (Cucumis sativus L.) were studied. The insect visitors in decreasing order of abundance were: Formica $s p .>$ Apis mellifera $>$ Apis cerana $>$ syrphids $\geq$ Apis dorstata. The activity of insects was peaked at 08.00-09.00 am. The foraging behaviour of A. mellifera was also studied. The bees spent significantly more time per flower during morning hours (sec/flower) and foraged significantly fewer flowers ( 7.9 flowers $/ \mathrm{min}$ ) compared to evening hours. There were significantly more nectar foragers $\left(6.03 / \mathrm{m}^{2} / 10 \mathrm{~min}\right)$ than pollen foragers $\left(5.16 / \mathrm{m}^{2} / 10 \mathrm{~min}\right)$. Most pollen foragers were observed during morning hours $\left(6.59 / \mathrm{m}^{2} / 10 \mathrm{~min}\right)$ whereas nectar foragers were most active during noon hours $\left(6.63 / \mathrm{m}^{2} / 10 \mathrm{~min}\right)$. Highest fruit set was observed in hand pollination (70.68\%). Percentage of misshapen fruits was maximum in without honey bee pollination $(24.35 \%)$. Without honey bee pollination resulted in significantly lowest percentage of healthy fruits $(75.25 \%)$. Hand pollination ranked highest among the three forms of pollination in respective of fruits $(985.13 \mathrm{~g})$, number of seeds per fruit $(425.22)$, fruit diameter $(27.1 \mathrm{~cm})$, fruit length $(26.7$ $\mathrm{cm})$ and weight of 1000 -seeds $(28.64 \mathrm{~g})$.
\end{abstract}

Key words: Insect, cucumber, yeild

\section{INTRODUCTION}

Cucumber (Cucumis sativus L.) is one of the oldest vegetables that is cultivated world-wide in tropical and subtropical parts of the world. Cucumis sativus L. commonly known as 'Shosha' in Bengali which is one of the most important vegetables belonging to the family Cucurbitaceae consumed as salad (Arunkumar et al. 2011). It has tremendous economic and dietic importance. The total production of cucumber in Bangladesh was about 63000 metric tons in 23000 acres in the year 2015-2016 (BBS 2016). The yield is very low compared to that of other developing countries. The potential yield of cucumber in our country is $15 \mathrm{t} / \mathrm{ha}$ (Rashid 1999). It is a good source of water, minerals, carbohydrates, protein, lipid, iron and vitamins in human diet. Both male and female cucumber flowers produce nectar and most of the bee visitors collect nectar from these. The male flowers appear first and in considerably larger number than the female flowers. The male flowers usually appear 10 days before the first female flowers appear (Judson 1929). They normally outnumber the female flowers about 10 to 1 in ordinary monoecious variety (Alex 1957a). During 1970's a revolution occurred in cucumber production with the introduction of gynoecious varieties which bear predominantly female flowers and provide uniform crop suitable for one single machine harvest (Lord 1985). Pollen for gynoecious varieties is provided by monoecious plants cultivated alongside them. Due to the presence of separate male and female flowers, it requires some external agents for successful pollination. The cucumber flowers are not wind or selfpollinated and mainly insects are the major pollinators of cucumber flower especially honey bees. Since the plant typically produce small amount of pollen, pollinators are needed for efficient pollen transfer from one flower to other to have good fruit set. Predominantly gynoecious (female flowering) cucumbers grown for machine harvest are in particular need of an abundant pollinator force because of the high density of planting (50,000-250,000 plants/ha) (Motes 1977, Van 1993).

The flower of cucumber remains open only for a single day, if they are not pollinated during that time the flower abort and drop from the vine. When incomplete pollination occurs but is incomplete, fruits do not develop properly (Hodges and Baxendale 1991). Inadequate pollination results in small or 
misshapen fruit and low yield of marketable fruits. Therefore, keeping in view the pollination requirements of cucumber, the present investigations were carried out to know the role of insect pollinator on the fruit set and quality of cucumber. The present investigations have been designed with a view to identify various types of insect visitors and their abundance in cucumber flowers as well as to study the effect of pollination on fruit yield of cucumber.

\section{MATERIAL AND METHODS}

The experiment was conducted at the Research Farm of Sher-e-Bangla Agricultural University, Dhaka in 2017 to find out the diversity and effect of pollinators on cucumber yield. Cucumber was used with three treatments (viz. Without bee pollination, Hand pollination, and Open pollination) in this study. The experiment was laid out in a Randomized Complete Block Design (RCBD) in eight replications in the year 2017. The planting was done in a plot size of $3.75 \mathrm{~m} \times 2.74 \mathrm{~m}$ at a distance of $0.5 \mathrm{~m} \times 0.5 \mathrm{~m}$ with six plants of each treatment, three plants being on each side of the plot. Good cucumber seeds were taken from the seed shop and soaked in water for 24 hours. Seedlings were raised in polythene bags and seedlings were planted as per spacing in the evening for reducing settlement stress. Cowdung, ash and water hyacinth were given to every pit at the rate of 5-6 kg, and each pit was supplied with $100 \mathrm{~g}$ TSP and 60-70 g MP fertilizer with a fixed supplement of $50 \mathrm{~g}$ urea after every 15 days. Irrigation and weeding were maintained as per necessity. The insects visiting on cucumber flowers were collected with the help of an usual cone type hand net. Insect collection was started after three days of commencement of flowering and continued till 90 percent of flowering was over. Collected insects were identified by comparing them with the identified species maintained in the Department of Entomology, SAU. Sweeps were made throughout the flowering of cucumber at 08.00-09.00, 11.00-12.00 and 14.00$15.00,17.00-18.00,20.00-21.00$ hours of the day. Insects were then killed in pure benzene and preserved as dry specimens.

For relative abundance of insect visitors, plants were selected randomly in three different plots and observations were started 2-3 days after flowering. These observations were taken between 08.00-09.00, 11.00-12.00 and 14.00-15.00, 17.00-18.00, 20.00-21.00 hours of the days and were continued for 7 sunny days. The number of A. mellifera bees foraging for pollen or nectar was recorded in one-meter square flower area per ten minutes during 08.00-09.00, 11.00-12.00 and 14.00-15.00 hours of the day. In total 18 observations were made during six days of observation. To study the 'without bee pollination' treatment, three selected plots were caged in 40 mesh nylon net and no bee was allowed to get in to the net. In case of open pollination, the selected cucumber plots were left open for the access of insect pollinators. On the other hand, to study the hand pollination, the male and female flowers of selected plants were bagged with butter paper bag one day prior to anthesis. Afterwards, when anthesis took place, butter paper bags were opened and petals of male flower were removed. Pollen from bagged male flowers was dusted over the female flowers by gently rubbing the anthers on the stigma; then again, the flowers were bagged for 2-3 days to avoid any contamination by foreign pollens. After 3-4 days of pollination, the bags were removed. Percent fruit set was calculated by dividing the numbers of fruits formed in each treatment over total number of female flowers multiply by 100.

For estimation of fruit weight in different modes of pollination five fruits were selected randomly from each treatment and replicated thrice. The polar length of the selected five fruits was recorded in $\mathrm{cm}$ and mean values were calculated. The fruit width in the middle was measured in $\mathrm{cm}$ on the selected five fruits and mean values were calculated. After recording fruit length and fruit breadth the seeds were extracted from individual fruit separately to count the number of seeds per fruit and mean values were recorded. Finally, five representative samples of 1000-seeds were taken from each treatment to determine the average 1000 seed weight in grams. The data were statistically analyzed using randomized 
block design after proper transformation wherever needed (Gomez and Gomez 1986). Graphical data representation, ANOVA, Multiple Range Test, Fisher's LSD and the P value calculated by Statgraphics Centurion XV.I version were followed.

\section{RESULTS AND DISCUSSION}

In total 11 insect species belonging to 11 genera under seven families visiting the cucumber bloom were recorded during the study period. Out of these, two species belonged to Diptera, four to Coleoptera and six to Hymenoptera. Among these, most frequent insect visitor was Formica sp., Apis mellifera was frequent visitor, whereas Syrphid and Apis cerana were less frequent visitors (Table 1).

Table 1. Frequency of insect visits on cucumber flower.

\begin{tabular}{lllcc}
\hline Common Name & Scientific Name & Family & Order & Frequency of visits \\
\hline Indian Honey bee & Apis cerana F. & Apidae & Hymenoptera & $* *$ \\
Rock bee & A. dorsata F. & Apidae & Hymenoptera & $*$ \\
Italian Honey bee & A. mellifera L. & Apidae & Hymenoptera & $* * *$ \\
Little honey bee & Apis florae & Apidae & Hymenoptera & $*$ \\
Ants & Formica sp. & Formicidae & Hymenoptera & $* * *$ \\
Syrphid fly & Episyrphus balteatus (DeGeer) & Syrphidae & Diptera & $*$ \\
Syrphid fly & Scaeva pyrastri L. & Syrphidae & Diptera & $*$ \\
Red pumpkin beetle & Aulacophora foveicollis L. & Chrysomelidae & Coleoptera & $*$ \\
Spotted cucumber beetle & Diabrotica undecimpunctata Mann & Chrysomelidae & Coleoptera & $*$ \\
Ladybird beetle & Coccinella septempunctata L. & Coccinellidae & Coleoptera & $*$ \\
Blister beetle & Mylabris pustulate T. & Meloidae & Coleoptera & $*$ \\
\hline
\end{tabular}

Asterisks of three different level is used to illustrate the degree of visit frequency; $*\left(0.01-1\right.$ mean visits $\left./ 10 \mathrm{~min} / \mathrm{m}^{2}\right)=$ Less frequent visitors; $* *\left(1-5\right.$ mean visits $\left./ 10 \mathrm{~min} / \mathrm{m}^{2}\right)=$ Frequent visitor; $* * *\left(6-10\right.$ mean visits $\left./ 10 \mathrm{~min} / \mathrm{m}^{2}\right)=$ Most frequent visitors

Data on the relative abundance of insect visitors during different hours of the day are presented in Table 2. During all four hours (viz. 8.00-9.00, 11.00-12.00, 14.00-15.00, 1700-18.00) except 20.0021.00 hrs Formica sp. were significantly most abundant (14.94, 13.6, 9.96, 7.71 and 0.2 counts $/ \mathrm{m}^{2} / 10 \mathrm{~min}$ respectively) whereas Syrphids were least abundant $(0.56,0.51,0.53,0.36$ and 0 counts $/ \mathrm{m}^{2} / 10 \mathrm{~min}$ respectively) in all periods. However, during 20.00-21.00 hrs, Apis florea was the most abundant visitor $\left(0.33\right.$ bees $\left./ \mathrm{m}^{2} / 10 \mathrm{~min}\right)$. Our results are in conformity with Grewal and Sidhu (1978); they observed the insect visitors of cucumber in Punjab and found that Apis florea, A. dorsata, A. mellifera and solitary bees, were the main visitors of the crop. However, Skrebtsova (1964) stated that honey bees are the only pollinators present in many U.S. fields and represent 84 to 96 percent of insect pollinators on cucumber.

Table 2. Average visit of insects on cucumber flower per 10 minutes per $\mathbf{m}^{2}$ area (six observations/hour).

\begin{tabular}{lccccccc}
\hline Hours & A. cerana & A. mellifera & A. dorsata & A. florea & Formica sp. & Syrphids & Mean \\
\hline $08.00-09.00 \mathrm{hrs}$ & 1.18 & 3.46 & 3.32 & 1.27 & 14.94 & 0.56 & 3.775 \\
$11.00-12.00 \mathrm{hrs}$ & 1.13 & 2.7 & 2.22 & 1.08 & 13.6 & 0.51 & 3.257 \\
$14.00-15.00 \mathrm{hrs}$ & 0.62 & 1.86 & 1.91 & 0.68 & 9.96 & 0.53 & 2.36 \\
$17.00-18.00 \mathrm{hrs}$ & 0.27 & 0.93 & 0.93 & 0.27 & 7.71 & 0.36 & 1.57 \\
$20.00-21.00 \mathrm{hrs}$ & 0 & 0 & 0 & 0.33 & 0.2 & 0 & 0.075 \\
\hline Mean & 0.64 & 1.79 & 1.676 & 0.726 & 9.282 & 0.392 & \\
\hline
\end{tabular}

The present findings reveal that the highest abundance of insects was at 08.00-09.00 hour while the lowest abundance was recorded from 20.00-21.00 hours. Shemetkov (1960) in Russia and Amaral et al. (1963) in Brazil reported that bees collected cucumber pollen heavily from 8 to 10 am and nectar from 
10 am to noon. Sajjanar et al. (2004) observed that under caged conditions, pollen foragers of A. cerana initiated activity by 06.00 hour. The activity was at a peak ( 6 bees $/ \mathrm{m} 2 / 5 \mathrm{~min}$ ) by 10.00 hour and then declined gradually till 18.00 hour (Fig. 1). Data on the proportion of nectar or pollen foragers of $A$. mellifera bees at different hours of the day on the cucumber bloom are presented in Table 3. It is revealed that irrespective of the day hours there were more number of nectar foragers with an average of $6.03 \mathrm{bees} / \mathrm{m}^{2} / 10 \mathrm{~min}$ as compared to pollen foragers $\left(5.16 \mathrm{bees} / \mathrm{m}^{2} / 10 \mathrm{~min}\right)$ and the difference was statistically significant.

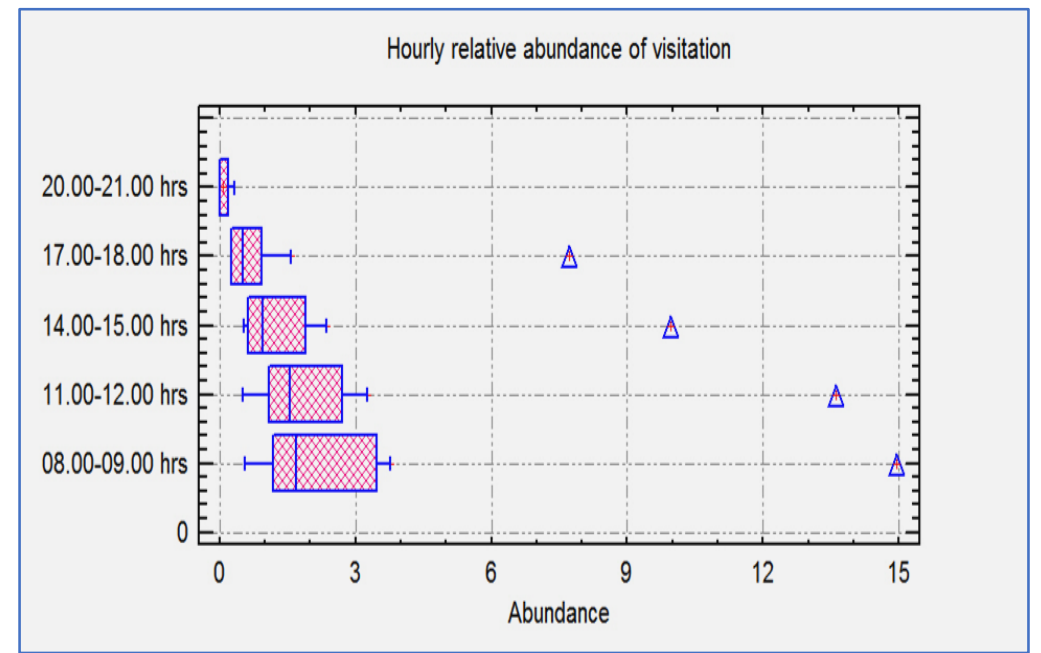

Fig. 1. Hourly relative abundance of visitation.

During 11.00-12.00 and 14.00-15.00 hrs, the average number of nectar foragers were significantly higher ( 6.63 and 5.85 bees $/ \mathrm{m}^{2} / 10$ min respectively) than pollen foragers ( 4.88 and 4.00 bees $/ \mathrm{m}^{2} / 10 \mathrm{~min}$, respectively). However, during 08.00-09.00 hrs, the average numbers of pollen foragers (6.59 bees $/ \mathrm{m}^{2} / 10 \mathrm{~min}$ ) were significantly higher than nectar foragers $\left(5.62 \mathrm{bees} / \mathrm{m}^{2} / 10 \mathrm{~min}\right)$ (Table 3). Similar results have also been observed by several other researchers (Kauffeld and Williams 1972, Collison and Martin 1975, Collision and Martin 1979). Rao and Suryanarayana (1988) and Sajjanar et al. (2004) also reported the maximum pollen foraging during morning hours and maximum nectar foraging during afternoon in cucurbit flowers.

Table 3. Proportion of Apis mellifera bees foraging for pollen or nectar per 10 minutes per $\mathbf{m}^{2}$ cucumber bloom at different hours.

\begin{tabular}{llll}
\hline Day hours & Pollen & Nectar & Mean \\
\hline $08.00-09.00$ & 6.59 & 5.62 & 6.105 \\
$11.00-12.00$ & 4.88 & 6.63 & 5.755 \\
$14.00-15.00$ & 4 & 5.85 & 4.925 \\
Mean & 5.16 & 6.03 & \\
\hline
\end{tabular}

$\mathrm{CD}_{0.05}$; Foragers 0.32; Day hours 0.39; Day hours x foragers 0.56

The data illustrated in Table 4 revealed that the percent of fruit set was significantly higher in hand pollination (70.68\%) and open pollination (62.09\%) than 'without honey bee' pollination (48.96\%). The findings show that the percentage of healthy fruits was maximum in hand pollination $(85.50 \%)$ followed by open pollination $(79.64 \%)$ and the minimum percentage of healthy fruits was observed in 'without honey bee' pollination $(75.25 \%)$ and all of them were statistically different from each other. Among different modes of pollination, the fruit set was significantly higher in hand polination, HP (70.68\%) and 
open pollination, OP (61.92\%) as compared to without bee pollination, WBP (48.96\%). This might be due to the reason that in hand pollination pollen is applied generously to whole stigmatic surface. Mouzin et al. (1980), Cervancia and Bergonia (1991) and Lemasson (1987) also obtained higher percentage of fruit set in BP as compared to OP. So in the absence of bee there was lack of pollination. The fruits obtained from OP $(20.25 \%)$ and HP (14.1\%) were also found to be better with respect to shape since the percentage of malformed fruits (misshapen) was the highest in WBP (24.35\%). Therefore, the percentage of well-formed healthy fruits was the highest in HP (85.5\%) followed by OP (79.64\%) and WBP (75.25\%), in accordance with the results of Cervancia and Bergonia (1991), Kato and Couto (2002) and Hernandez et al. (1999), which might be attributed to sufficient amount of pollen being received by the flowers in HP and BP treatments.

Table 4. Effect of different modes of pollination on percent fruit set, crooked and healthy fruits.

\begin{tabular}{llll}
\hline Mode of pollination & Fruit set (\%) & Misshapen fruits (\%) & $\begin{array}{l}\text { Healthy fruits } \\
(\boldsymbol{\%})\end{array}$ \\
\hline Without Honeybee & 48.96 & 24.35 & 75.25 \\
Open & 61.92 & 20.25 & 79.64 \\
Hand & 70.68 & 14.1 & 85.5 \\
\hline $\mathrm{CD}_{0.05}$ & 0.98 & 0.76 & 0.69 \\
\hline
\end{tabular}

Table 5 shows that the weight of fruit was significantly higher in hand pollination $(985.13 \mathrm{~g})$ and open pollination (977.87 g) and significantly lower without bee pollination (WBP) mode of pollination $(770.51 \mathrm{~g})$. The maximum number of seeds per fruit was observed in hand pollination (425.22 seeds/fruit) and minimum in 'without bee pollination' (390.56 seeds/fruit), the latter being statistically at par with open pollination (403.43 seeds/fruit). On the other hand, in Fig. 5, some other parameters are illustrated of the study. It is showing that fruit diameter was higher in hand pollination with an average of $27.1 \mathrm{~cm} /$ fruit whereas significantly lower fruit diameter was found in without bee pollination $(23.9$ $\mathrm{cm} /$ fruit).

Table 5. Effect of different modes of pollination on fruit weight and number of seeds/fruit at the time of seed harvesting.

\begin{tabular}{llllll}
\hline $\begin{array}{l}\text { Mode of } \\
\text { Pollination }\end{array}$ & $\begin{array}{l}\text { Weight of } \\
\text { fruit }(\mathbf{g})\end{array}$ & $\begin{array}{l}\text { No. of } \\
\text { seed/fruit }\end{array}$ & $\begin{array}{l}\text { Fruit diameter } \\
(\mathbf{c m})\end{array}$ & $\begin{array}{l}\text { Fruit length } \\
(\mathbf{c m})\end{array}$ & $\begin{array}{l}\text { 1000-seed } \\
\text { weight }(\mathbf{g})\end{array}$ \\
\hline Without Honeybee & 770.51 & 390.56 & 23.9 & 21.8 & 23.14 \\
Open & 977.87 & 403.43 & 26.8 & 26.5 & 27.73 \\
Hand & 985.13 & 425.22 & 27.1 & 26.7 & 28.64 \\
\hline $\mathrm{CD}_{0.05}$ & 47.65 & 27.93 & 0.82 & 0.63 & 0.91 \\
\hline
\end{tabular}

The fruit length was found to be higher in hand pollination $(26.7 \mathrm{~cm} /$ fruit $)$ and lower fruit diameter was found in without bee polllination $(21.8 \mathrm{~cm} /$ fruit). It is shown that the weight of seeds was significantly higher in hand pollination $(28.64 \mathrm{~g})$ followed by open pollination $(27.73 \mathrm{~g})$ and without bee pollination (27.73 g). Brewer (1974), Garcia et al. (1998) and Prakash et al. (2004) found that the number of seeds per fruit and larger fruit size in bee pollinated plants might be attributed to the sufficient number of pollen grains received by the flowers which were best provided by honey bees in caged conditions as compared to OP and HP. This also might be due to the adequate pollination done by honey bees inside the cage whereas this study obtained the lowest value in yield in case of without bee pollination.

The F-ratio, which in this case equals to 21.5837, is a ratio of the between-group estimate to the within-group estimate. Since the P-value of the F-test is less than 0.05 , there is a statistically significant 
difference between the means of the 3 variables (fruit diameter, fruit length and 1000-seed weight) at the $95.0 \%$ confidence level.

The present investigation was undertaken to determine the various insect visit variability and frequency of cucumber, their abundance, foraging behavior of major bee pollinators and effect of different modes of pollination on fruit and seed characters. In total eleven insect species were recorded that visited the cucumber bloom, out of which Formica sp. (9.24) were most abundant. The activity of insect visitors was peaked in the morning (3.78). There was significantly more number of nectar foragers $\left(6.03 / \mathrm{m}^{2} / 10 \mathrm{~min}\right)$ as compared to pollen foragers $\left(5.16 / \mathrm{m}^{2} / 10 \mathrm{~min}\right)$. The pollen foragers were the highest during morning hours $\left(6.59 / \mathrm{m}^{2} / 10 \mathrm{~min}\right)$, whereas the nectar foragers were the highest during noon hours $\left(6.63 / \mathrm{m}^{2} / 10 \mathrm{~min}\right)$. Among the different modes of pollination, the fruit set was the highest in hand pollination $(70.68 \%)$ and minimum in without bee pollination $(48.96 \%)$. The percentage of crooked fruits was the highest in WBP $(24.35 \%)$ and minimum in hand pollination (14.1\%) whereas the percentage of healthy fruits was the highest in hand pollination $(85.5 \%)$ and minimum in without bee pollination $(75.25 \%)$. The fruit weight $(985.13 \mathrm{~g})$, number of seeds per fruit $(425.22)$, fruit diameter $(27.1 \mathrm{~cm})$ and fruit length $(26.7 \mathrm{~cm})$ were the highest in hand pollination as compared to open and without bee pollination. The weight of 1000 -seeds was also significantly higher in hand pollination (28.64g) as compared to other modes of pollination. Since without bee pollination exhibits the lowest fruit set, healthy fruits, fruit weight, fruit size, number of seeds per fruit and weight hence we know Bee Pollination (A. millifera) resulted in higher fruit set, healthy fruits, fruit weight, fruit size, number of seeds per fruit and weight. So, in absence of bee pollinator hand pollination could be considered the best.

\section{REFERENCES}

Alex, A. H. 1957a. Honey bees aid pollination of cucumbers and cantaloupes. Texas Agricultural Experimental Station Progress Report, USA. 4 pp.

Amaral, E., J. Mitidieri and R. Vencousky. 1963. Studies on the activities of Apis mellifera L. while visiting the flowers of Cucumis sativus L. Olericultura (Brazil). 3: 181-193.

Arunkumar, K. H., M. G. Patil, C. N. Hanchinamani, I. S. Goud and S. V. Hiremath. 2011. Genetic relationship of growth and development traits with fruit yield in F2 population of BGDL $\times$ Hot season of cucumber (Cucumis sativus L.). Karnataka J. Agric. Sci. 24: 497-500.

BBS. 2016. Yearbook of Agricultural Statistics. Statistics and Informatics Division (SID), Bangladesh Bureau of Statistics (BBS), Ministry of Planning, Government of the People's Republic of Bangladesh. 41 pp.

Brewer, J. W. 1974. Pollination requirement for watermelon seed production. Apic. J. Res. 13(3): 207212.

Cervancia, C. R. and E. A. Bergonia. 1991. Insect pollination of cucumber (Cucumis sativus L.) in the Philippines. Ada Hort. 288: 278-282.

Collision, C. H. and E. C. Martin. 1975. A scanning electron microscope study of cucumber (Cucumis sativus) nectaries. Apic. J. Res. 14: 79-84.

Collision, C. H. and E. C. Martin. 1979. Behaviour of honey bees foraging on male and female flowers of Cucumis sativus. Apic. J. Res.18: 184-190. 
Garcia, R. C., F. V. Resende, A. A. Marcosa, D. P. Toloi, J. A. G. Faleiros, R. P. Turquino and S. De. Souza. 1998. Study of melon (Cucumis melo) pollination by Apis mellifera in the greenhouse. UNIMAR Ciencias. 7(2): 123-131.

Gomez, K. A. and A. A. Gomez. 1986. Statistical procedure for agricultural research. 3rd ed. John Willey and Sons, New York, UK. 680 pp.

Grewal, G. S. and G. Sidhu. 1978. Insect pollination of some cucurbits in Punjab. Indian Agric. J. Sci. 48: 79-83.

Hernandez, S. J. C. and I. Lemus. 1999. Yearly output in pumpkin using the honey bee (Apis mellifera) as pollinating insect. Apiacta. 34(4): 104-106.

Hodges, L. and F. Baxendale. 1991. Bee pollination of cucurbit crops. Report of University of Nebraska Lincoln Cooperative Extension, NF91-50.

Judson, J. E. 1929. Morphology and vascular anatomy of the pistillate flowers of the cucumber. American J. Bot. 16: 69-89.

Kato, E. C. and R. H. N. Couto. 2002. Pollination of winter melon and net melon, Cucumis melo L. Naturalia. 27: 201-210.

Kauffeld, N. M. and P. H. Williams. 1972. Honey bees as pollinators of pickling cucumbers in Wisconsin. Am. J. Bot. 112: 252-254.

Lemasson, M. 1987. Contribution of the honey bees to the pollination of greenhouse grown plants of gherkin, melon and tomato. Revue de l' Agriculture. 40(4): 915-924.

Lord, W. G. 1985. Successful cucumber production will continue to depend on honey bees in the near future. Am. J. Bee. 125: 623-625.

Motes, J. E. 1977. Pickling cucumbers: production harvesting. Michigan State University Extension Bulletin, E-837.

Mouzin, T. E., D. K. Reedand and W. E. Chaney. 1980. Influence of honey bees on cantaloupe production in Indiana. Proc. Indiana Acad. Sci. 89: 215-217.

Prakash, K. B., S. M. Sajjanar, G. Kuberappa, H. P. Prabhuswamy and G. Eswarappa. 2004. Effect of number of bee visits on fruit set and some fruit characters in Cucumis sativus L. Adv. Pollen Spore Res. 22: 127-130.

Rao, G. M. and M. C. Suryanarayana. 1988. Studies on the pollination of watermelon Citrullus lanatus (Thumb.). Indian J. Bee. 50: 5-8.

Rashid, M. M. 1999. Sabgi Biggan (in Bangla). Rashid Publishing House, Dhaka. 303 pp.

Sajjanar, S. M., G. C. Kuberappa and H. P. Prabhuswamy. 2004. Insect visitors of cucumber (Cucumis sativus L.) and the role of honey bee Apis cerana F. in its pollination. Pest Manag. Econo. Zool. 12(1): 23-31.

Shemetkov, M. F. 1960. Pollinating activity of bees in greenhouses. Pchelovodstvo. 37(1): 28-31.

Skrebtsova, N. D. 1964. Use of pollinating activity of honey bees for developing hybrid vegetable seed. Trud. Nauch Issled. Inst. Pchelovod. Selsk. Khoz. Rybnoe. 12: 223-245.

Van, W. E. 1993. Cucumber yield response to plant density and spatial arrangement. Prod. J. Agric. 6: 253-255. 
